\title{
Farm Women and their Contribution in Livestock Management in Kadapa District of Andhra Pradesh, India
}

\author{
D. M. Cherryl" and D. Indira \\ Department of Livestock Production Management, College of Veterinary Science, \\ Proddatur, Kadapa, Andhra Pradesh, India \\ *Corresponding author:
}

\section{A B S T R A C T}

Ke y w o r d s
Rural women,
Grazing, Marketing,
Management

\section{Introduction}

Majority of the women in Indian villages are actively occupied in agriculture and livestock sector. They play most significant and crucial role in management and development of livestock sector (Behera and Behera, 2013). Their involvement may differ from one region to other and this variation may depend on several factors like family obligations, socioeconomic status, class, caste, farming type, etc. It is accepted that managing livestock has always been considered as the traditional responsibility of women (Arshad et al., 2013). Women provide the main source of labour for all the livestock and its related activities
(Oluka, 2006) like feeding, watering, milking, breeding, health care, cleaning, etc and also earn livelihood for the family and take care of the nutritional security.

In this context efforts were made with the specific objective of evaluating the participation of women in different on farm and off farm livestock activities in Kadapa district of Andhra Pradesh, India. Simultaneously, the effect of various socioeconomic factors such as age, education, land holding and animal holding on the women's participation in various livestock activities was analyzed. 


\section{Materials and Methods}

The study was planned and carried out among the rural women farmers of Kadapa district. From the selected district, six mandals were selected, from which two villages were selected randomly. 20 women farmers were further selected randomly from those six mandals i.e. 10 from each village.

Hence a sample of 120 female respondents who had at least one dairy animal were randomly selected from 6 mandals of Kadapa district of Andhra Pradesh and interviewed. In order to observe the role played by women farmers in different livestock related activities, a set of related questions were asked.

The check list contained vital roles involved in livestock production viz., grazing, cleaning, breeding, fodder cutting, feeding, watering, health care of animals, marketing, manure collection, milking, calf rearing etc. Thus the respondents gave information related to their participation in various activities of livestock.

Further, in order to study the impact of various socio-economic factors parameters such as age, education, size of land, animal holding were also documented. Based on the age the respondents were classified into groups i.e. <25years, 25-50 years, and >50 years while the level of education was categorized as illiterate, primary level and middle level or above.

On the basis of land holdings the respondents were distributed into big (>6ha), small (1-6 ha), marginal ( $<1 \mathrm{ha})$ and landless farmers. Finally on the basis of number of animals maintained the respondents were grouped into three categories i.e. 1-2, 3-4 and 5 and above. The data collected was tabulated and analyzed to derive at logical conclusions using suitable statistical procedures.

\section{Results and Discussion}

In this study it was observed that majority of the women farmers $(56.67 \%)$ were between 25-50 years, 25 percent were above 50 years and about 18.33 percent were below the age of 25 years. These results were similar to Mishra et al., (2008). Almost half of the women respondents were illiterate $(81.67 \%)$, 14.17 percent studied up to primary level and only 4.17 percent had secondary and above education. The findings were in agreement with Mishra et al., (2008)

Based on the land holding, the percentage of women respondents as big farmers, small farmers, marginal farmers and landless were $6.67,20.83,44.17$ and 28.73 percent, respectively.

On the basis of number of animals maintained, the respondents were classified into three categories i.e.1-2, 3-4, 5 and above respectively. Results show that most (44.17\%) of the respondents had 3-4 animals which was found to be deferred with the results given by Arshad et al., (2013). Further in this study, 35.83 percent of the women farmers owned 12 animals and about 20 percent had five or more animals. From the above data it could be inferred that most of the farm women are between the age of 25-50 years, illiterate, marginal farmers owning 3-4 animals for their livelihood.

Contribution of women workforce in livestock enterprise was estimated in terms of their role performance in different animal husbandry operations and their involvement in decision making process was also analyzed. The rural women of Kadapa district play a vital role in livestock production activities. Their participation is highly dispersed as they are engaged in various activities related to animal husbandry (Table 1). 
Table.1 Distribution of farm women according to their socio economic characteristic

\begin{tabular}{|c|c|c|}
\hline Character & Group & Percent \\
\hline Age & $<25$ Years & 18.33 \\
\hline & $25-50 \mathrm{Yrs}$ & 56.67 \\
\hline & $>50$ yrs & 25.00 \\
\hline & & 100 \\
\hline Education & Illiterate & 81.67 \\
\hline & Primary & 14.17 \\
\hline & Middle and above & 4.17 \\
\hline & & 100 \\
\hline Land Holding & Big Farmers & 6.67 \\
\hline & Small Farmers & 20.83 \\
\hline & Marginal Farmers & 44.17 \\
\hline & Landless farmers & 28.33 \\
\hline & & 100 \\
\hline Animal holding & $1-2$ & 35.83 \\
\hline & $3-4$ & 44.17 \\
\hline & 5 and $>5$ & 20.00 \\
\hline
\end{tabular}

Table.2 Distribution of Women respondents based on specific tasks performed by them related to livestock

\begin{tabular}{|l|l|}
\hline Tasks related to livestock production & \multicolumn{1}{|c|}{} \\
\hline Grazing & 71.67 \\
\hline Cleaning of animals & 77.50 \\
\hline Cleaning of shed & 81.67 \\
\hline Breeding of animals & 25.0 \\
\hline Caring of diseased animals & 51.67 \\
\hline Marketing & 60.0 \\
\hline Fodder cutting & 50.0 \\
\hline Fodder carrying & 47.50 \\
\hline Fodder chopping & 45.0 \\
\hline Making feed concentrate & 33.33 \\
\hline Feeding at home & 81.67 \\
\hline Watering of animals & 89.17 \\
\hline Manure Collection & 80.83 \\
\hline Making dung cakes & 44.17 \\
\hline Milking & 52.50 \\
\hline Calf rearing & 73.33 \\
\hline
\end{tabular}

From the observations recorded, it was studied that rural women were involved in a wide range of livestock management practices like grazing $(71.67 \%)$, cleaning of animals $(77.5 \%)$, cleaning of shed $(81.67 \%)$, breeding $(25 \%)$, health acre of animals $(51.67 \%)$, 
marketing (60\%), fodder cutting (41.67\%), fodder carrying $(47.50 \%)$, fodder chopping (45 \%), preparation of concentrate feed $(33.33 \%)$, feeding (81.67\%), watering (89.17\%), manure collection (80.83\%), making dung cakes (44.17\%), milking $(52.50 \%)$ and calf rearing $(73.33 \%)$. The present findings with regard to most of the tasks performed by women were found similar to Narmatha et al., (2009) and Arshad et al., (2013).

However, in few domains like fodder chopping, grazing management, making dung cakes and preparation of concentrate feed the results are contradictory to the above mentioned studies. It could be further inferred that majority of the livestock related works in comparison to men; women contributed more than 50 percent labour. Although in certain tasks, their labour contribution was slightly lower which may be due to the involvement of technology or because of cumbersome task.

Table 2 reveals that only 25 percent of the women were involved in breeding management because taking the animals for natural service or artificial insemination is mainly at times done by male member of the family and these findings were similar to Mishra et al., (2008). The extent of women involvement in feeding and watering the animals was found to be maximum as also reported by Narmatha et al., (2009). With regard to health care of animals, women folk involved almost equally with their counterparts and the findings were similar to Hai et al., (2011). From the data, it may be concluded that cleaning of animals, shed, calf rearing, milking of animals, manure collection were female dominated works and the same was also said by Narmatha et al., (2009).

It was observed from the study that about 60 percent of the women were also involved in marketing activity. Similarly Hai et al.,
(2011) observed in their study that 50 percent of the farm women involved in marketing of milk. Also these findings are in consonance with the reports of researchers Rathod et al., (2011). Role of women in livestock enterprise based on their involvement in various activities mainly depends upon the type of operations. Most of the indoor as well few outdoor operations were easily carried out by women folk. Although women as dairy farmers are coming forward in many villages, even then major decisions pertaining to finance or marketing are carried by men folk. These practices could be changed when women are made aware of their strength and importance in their family, society and villages. This can bring about a drastic change in the socio economic structure of India.

During the present study conducted, from the interview it was understood that although women were the main workforce involved in majority of the animal husbandry activities, for decision making is mainly by men. The income from dairy animals does not remain in the hands of women rather they are only considered to work and maintain the livestock. Women should equally participate in decision making process which will improve their confidence and wellbeing in the society. Hence it is necessary to encourage women to involve in all the financial decisions so that the family and the society gets empowered in true sense as women are the backbone of society.

\section{References}

Arshad, S., Muhammad, S. and Ashraf, I. 2013. Women's participation in livestock farming activities. The journal of Animal and Plant Sciences, 23(1): 304-308.

Behra, B. S. and Behera, A. C. 2013. Gender Issues: The role of women in Agriculture sector in India. 
International Journal of Marketing, financial services and management research, volume (2), 134-145.

Hai, A., Akand, A. H., Shanaz, S. and Bulbul, K.H. 2011. Contribution of Farm Women towards dairy enterprise in Ganderbal district of Kashmir Valley. Journal of dairying, foods and Home sciences, 30(2), 140-146.

Mishra, S., Sharma, S., Vasudevan, P., Bhatt, R.K., Pandey, S., Singh, M., Meena, B.S. and Pandey, S.N. 2008. Gender participation and role of women in livestock management practices in Bundelkhand region of Central India. International Journal of Rural studies, volume (15). Retrieved from http://www.ivcs.org.uk/IJRS.

Narmatha, N., Uma, V., Arun, L. and Geetha, R. 2009. Level of participation of women in livestock farming activities.
Tamil Nadu journal of Veterinary and Animal Sciences. Volume 5(1), 4-8.

Oluka, J., Owayesigire, B., Esenu, B. and Sewannyana, E. 2006. Small stock and women in livestock production in the Teso Farming System region of Uganda, Research project funded by UK Department for International Development for the benefit of developing countries. Proceedings of a workshop on enhancing the contribution of small livestock to the livelihoods of resource poor communities, Hotel Brovad, Masaka, Uganda, 15-19 Nov 2004.151-160.

Rathod, P. K., Nikam, T. R., and Landge, S. 2016. Participation of rural women in dairy farming in Karnataka. Indian Research Journal of Extension Education, 11(2), 31-36.

\section{How to cite this article:}

Cherryl, D. M. and Indira, D. 2020. Farm Women and their Contribution in Livestock Management in Kadapa District of Andhra Pradesh, India. Int.J.Curr.Microbiol.App.Sci. 9(09): 1739-1743. doi: https://doi.org/10.20546/ijcmas.2020.909.216 